\title{
Phytopanktonic composition and indicative species of water quality in high artificial ponds at Mexico city
}

\begin{abstract}
This study analyses the water quality and microalgae composition of an artificial reservoir in the Mexican basin called La Cantera, built in 2005. Thirteen years later (2018) it shows a change in both its chemistry and microalgae structure and a visible deterioration (eutrophication) due to several nearby internal academic and anthropogenic activities. This study has therefore assessed water quality by measuring concentrations of nitrogenated and phosphorus total inorganic nutrients $(>500 \mu \mathrm{M}$ and $120 \mu \mathrm{M}$, respectively) that showed an evident eutrophication. During our seven-year sampling period we found the following composition and predominance of algae of the taxa: Bacillariophyceae, Cyanoprokaryota and Chlorophyta. Results showed a predominance of the first biological taxa with nine indicative species of different contamination types with a preponderance of Navicula, and two in the case of the second taxa with a predominance of Microscystis.
\end{abstract}

Keywords: La Cantera, artificial reservoir, eutrophication, bacillariophyceae
Volume 3 Issue 5 - 2019

\author{
María Edith Ponce Marquez,' Guadalupe de \\ la Lanza Espino ${ }^{2}$ \\ 'Department of Comparative Biology, Faculty of Sciences, \\ National Autonomous University of Mexico, Mexico \\ ${ }^{2}$ Hydrobiology Laboratory, Institute of Biology, National \\ Autonomous University of Mexico, Mexico
}

Correspondence: Guadalupe de la Lanza Espino, Hydrobiology Laboratory, Institute of Biology, National Autonomous University of Mexico, Mexico, Tel +52 55562291 32, Email gdlle@unam.mx

Received: August 13, 2019| Published: September II, 2019

\section{Introduction}

Epicontinental bodies of water can be natural (e.g. lakes) or artificial (man-made). Studies on phytoplanktonic composition carried out in these bodies of water have been fundamentally taxonomic, and only until the beginning of this century they have focused on ecologically characterizing aquatic environments and using some genera and, specially, on pollution-indicator species. It should be noted that much of the composition is a consequence of several aquatic environmental factors such as physiochemical and climatic characteristics which adequate to phytoplanktonic blooms, mortality or natural time-space succession of phytoplankton. In man-made reservoirs, the variety of anthropogenic activities has changed these characteristics exceeding the recuperation capabilities or resilience of the chemical and biological composition.

Some artificial reservoirs or dams were built many centuries ago as water reservoirs for humans and their economic activities, as flood control, agricultural irrigation, electricity generation, sports and tourism, among others, activities that have generated all kinds pollution. A recent artificial reservoir is the A3 Buffer Zone inside the Pedregal de San Angel Ecological Reserve where the Cantera Oriente is located. The Cantera was given in concession to the federal government by the National Autonomous University of Mexico (UNAM) for the extraction of volcanic rock to produce asphalt used in construction. ${ }^{1}$ This industry was later abandoned and an aquatic system with exotic vegetation was created for research, teaching, conservation and recreation purposes. This author (Lot) had said that the Cantera, due to its origin, was a very damaged site and a real challenge for any lake landscape creation program; nevertheless, its ecological rehabilitation was attempted.

Given the interest in understanding the environmental dynamics of La Cantera, a number of individual studies have been developed in several specialties such as: geology, physics, chemistry and biology. However, most of these studies have been isolated, descriptive and, unfortunately, without integration. For example, specific biological studies on phytoplanktonic composition have been conducted in short periods of time, and in some of these, abundance has been associated with eutrophication. Water quality or physiochemistry has frequently been considered exclusively within the description of the study area and, in the best of cases, it has been used to briefly explain the presence of some species. The aim of this paper is to analyze the physiochemistry of the water and define the phytoplankton composition to gender level, and to find the indicator species of water quality.

\section{Material and method}

\section{Study area}

La Cantera was originally a place operated by an asphalt plant until a huge 16 hectares and 42meters deep hole was created. After exploiting it for $25 y$ years and seeing that water was beginning to leak from the bottom, it was finally closed. In 1996 the property was returned to the National Autonomous University of Mexico, UNAM (personal communication from Biologist Francisco Martínez, in charge of the place http://www.unamglobal.unam.mx/?p=46649). Today it is an artificial reservoir located southwest of Mexico City $\left(19^{\circ} 17^{\prime} \mathrm{N}, 99^{\circ} 11^{\prime} \mathrm{W}\right)$ within the University campus. It consists of five bodies of water surrounded by a $40 \mathrm{~m}$ high basalt wall, a total area of $11,906.45 \mathrm{~m}^{2}$ and an average depth of $2 \mathrm{~m}^{1}$ with large photoplanktonic growths. The surrounding vegetation is composed of xerophytic tree scrub with cypresses, tulars (herbaceous plants rooted in the bottom of swampy land or on the banks of lakes), as well as reforestation areas (Figure 1). On the surrounding area there is a dense urban population and a wide street with heavy vehicular traffic. The climate is temperate sub-humid with summer rains $[\mathrm{Cb}(\mathrm{w} 1) \mathrm{w}]$, and heavy rainfall from June to October and a dry season from November to May. Average annual temperature is $15.6^{\circ} \mathrm{C}$ and an average annual rainfall of $833 \mathrm{~mm}$. It consists of volcanic rock substrate originated from the eruption of the Xitle and Ajusco volcanoes about 1670years 
ago. Soil is scarce and shallow (Descriptive sheet of the Ecological Reserve of Pedregal de San Angel REPSA consulted in March 2019 http://www.repsa.unam.mx/index.php/ubicacion/mapa-del-sit io/44-2013-08-07-13-15-59/29). There is a seasonal loss of the water mirror. This artificial body is fed by springs and cracks from the Ajusco Hill.

Water samples were collected for the phycological study and physiochemical characteristics of water quality for seven years (2006, 2010, 2011, 2012, 2013, 2014, 2016), to estimate changing tendencies and, as far as possible, the distribution and association with physicochemical properties to be used as indicators of eutrophication, in 10 sites chosen for their geomorphology: five in lotic areas (runoff zones and natural and artificial canals) and in five lentic environments (Figure 2).
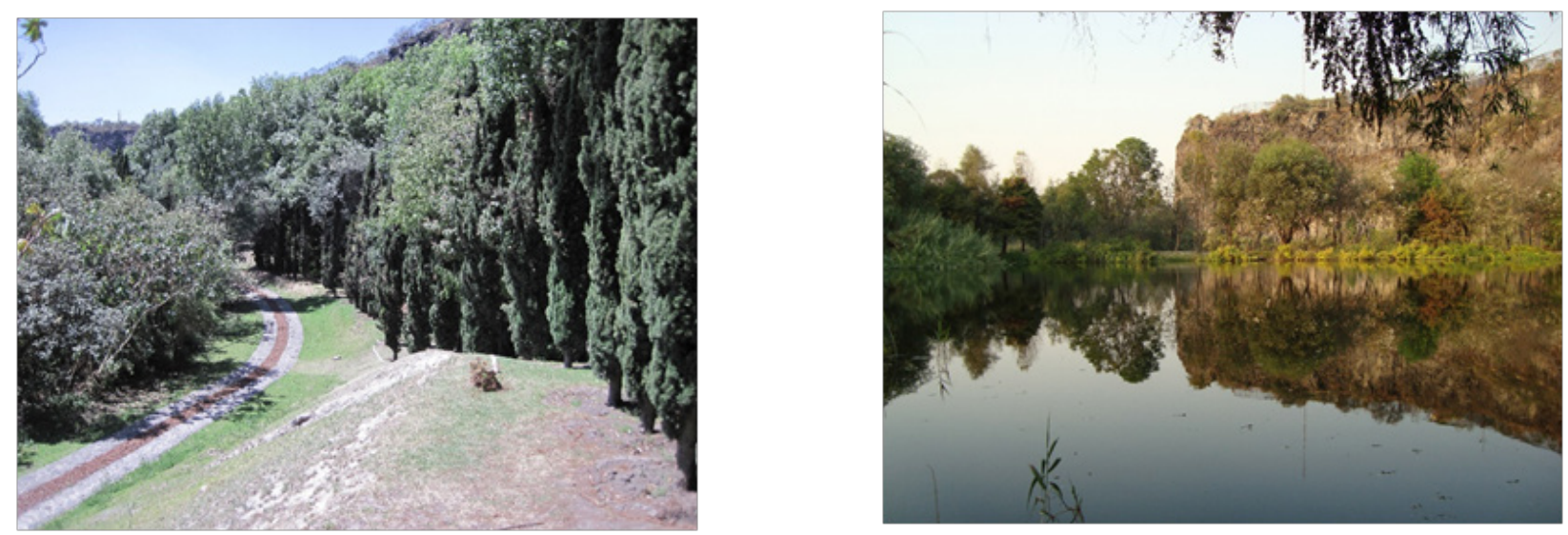

Figure I Buffer Zone A3 “La Cantera Oriente” (Eastern Cantera).

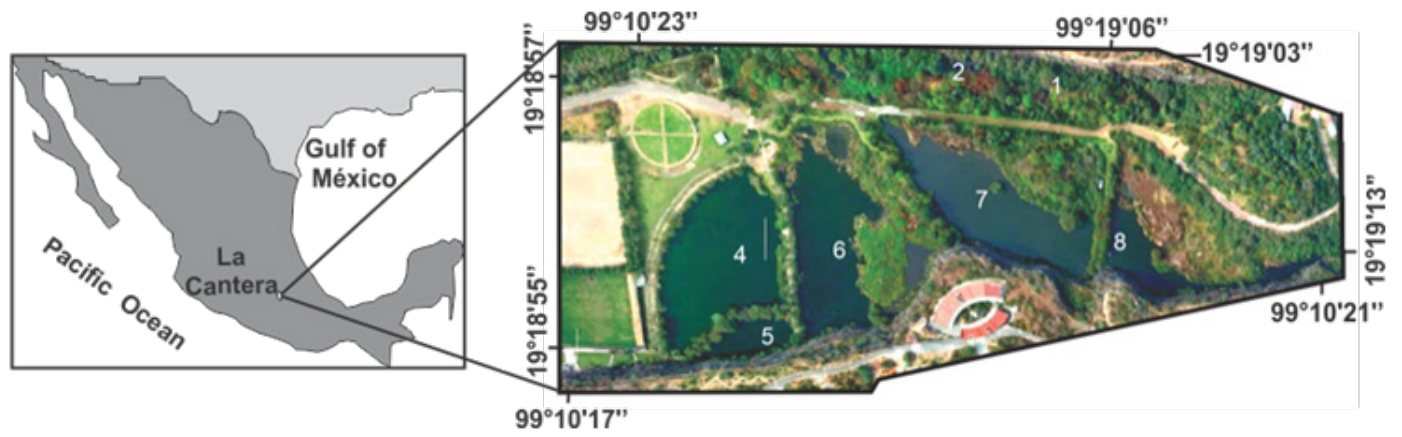

Figure 2 Ubication of La Cantera and sampling sites.

\section{Field work}

Temperature, $\mathrm{pH}$, conductivity and dissolved oxygen measurements were taken in situ with a conductometer/potentiometer (Hach). Chemical analyses were done on water samples showing the presence of nitrates, nitrites, total phosphorus, hardness, silicates, among others (with the Hach portable equipment). The visible epiphyte algae material was collected by hand with spatula and tweezers from a $4 \mathrm{~cm}^{2}$ area. Diatoms were collected from rock scrapings. Perifiton (epiphytic algae) was obtained by compressing some of the surrounding vegetation. On water from the lake we used a phytoplankton net (with a mesh opening of 10microns) which could be dragged approximately three meters. ${ }^{2}$ Samples were kept in $30 \mathrm{ml} / 50 \mathrm{ml}$ polyethylene bottles with $3 \%$ formalin. For diatom determination (essential component of the algal community), organic matter was eliminated using the acid oxidation technique; mounted on synthetic resin. ${ }^{3}$

The Hoek et al. ${ }^{5}$ scheme was used to identify the genera besides the following fundamental references for Cyanoprokaryota: Komárek et al., ${ }^{5}$ for Bacillariophyceae. Round et al., ${ }^{6}$ for Xanthophyceae, Ettl, ${ }^{7}$ for Chlorophyta, Ettl and Gardner ${ }^{8}$ among others.

\section{Results}

Variations in conservative parameters such as temperature and conductivity showed a wide variation between 12 to $20^{\circ} \mathrm{C}$ and 400 to $528 \mu \mathrm{S} / \mathrm{cm}^{2}$ respectively as a result of seasonal and interannual seasonality, evident even during the time of measurement taking. Conductivity levels exceeded those established for freshwater $(100 \mu \mathrm{S} /$ $\mathrm{cm}^{2}$ ); however, total hardness ranged from 68 to $170 \mathrm{mg} / \mathrm{L}$ so the water from the La Cantera can be considered from soft, semi-hard to moderately hard. Silicate concentrations ranged from 18 to $45 \mathrm{mg} / \mathrm{L}$, the latter being due to the high density of diatoms. Concentrations of nitrogenated nutrients (nitrites, nitrates, ammonium) and total phosphorus were variable and generally high, exceeding the contents of natural water, making the Cantera a hyper-eutrophicated place (Table 1).

The largest taxa from the six identified in the La Cantera in 2006 and 2016 was Bacillariophyceae ( 49 and $81 \%$, respectively), followed by Cyanoprokarota (18 and 14\%), Chlorophyta (25 and 50\%). The rest were: Euglenophyta, Ochrophyta, Xantophyceae the less abundant (Figure 3). An analysis of all sampled years, within the Cyanoprokarota, the predominant genera were Anabaena, Phormidium, Chroococcus 
and Microscystis, followed by Planktothrix and Scytonema. The important genera of Bacillariophyceae were Achnanthes, Aulacoseira, Cyclotella and Rhoicosphenia. Of Euglenophyta: Euglena and Phacus with low percentages. The Ochrophyta Division and the genera Xenococcus from Cyanoprokarota were the least abundant.

Table I Physiochemical characteristics of the Cantera pond water

\begin{tabular}{ll}
\hline Temperature ${ }^{\circ} \mathrm{C}$ & 20-Dec \\
\hline Conductivity $\mu \mathrm{S} \mathrm{cm}^{-1}$ & $400-528$ \\
$\mathrm{SiO}_{4} \mathrm{mg} / \mathrm{L}$ & $13-6 \mathrm{I}$ \\
$\mathrm{pH}$ & $6.0-10$ \\
Nitrates $\mu \mathrm{M}$ & Oct-57 \\
Nitrites $\mu \mathrm{M}$ & $0.2-8.0$ \\
Total Phosphorous $\mu \mathrm{M}$ & $35-142$ \\
Ammonioum $\mu \mathrm{M}$ & $6.0-27.0$ \\
Silicates $\mathrm{mg} / \mathrm{L}$ & $8.4-62$ \\
Hardness $\mathrm{mg} / \mathrm{L}$ & $68-170$ \\
\hline
\end{tabular}

Figure 3 Comparative percentual composition and their pay representative distribution, between 2006 and 2016 of taxa found in La Cantera.

\begin{tabular}{lll}
\hline & $\mathbf{2 0 0 6}$ & $\%$ \\
\hline Cyanophyta & 22 & 18.03 \\
Chlorophyta & 30 & 24.75 \\
Charophyta & 4 & 3.27 \\
Euglenophyta & 4 & 3.27 \\
Ochrophyta & 1 & 0.83 \\
Cryptophyta & 0 & 0 \\
Xantophyceae & 1 & 0.83 \\
Bacillariophyceae & 60 & 49.02 \\
& 122 & 100
\end{tabular}

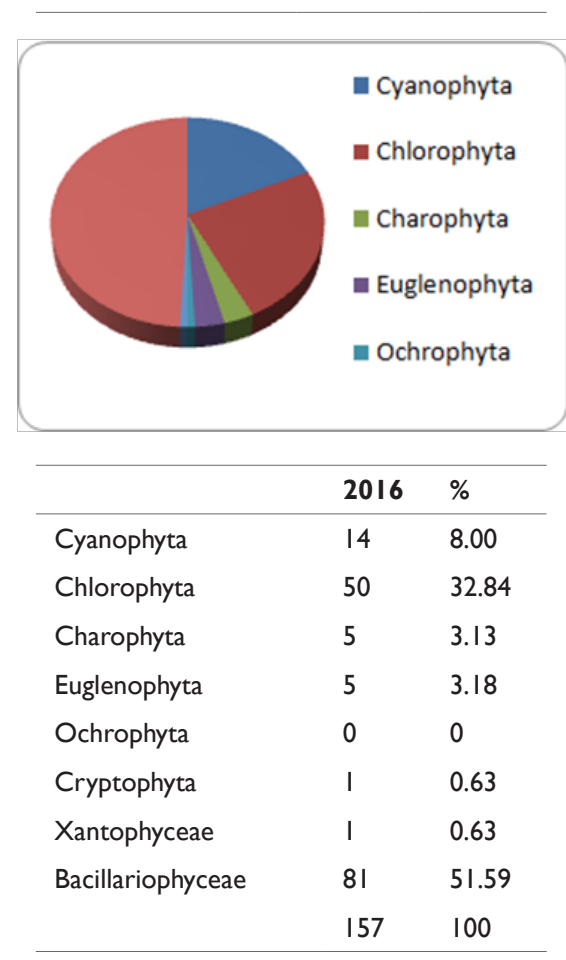

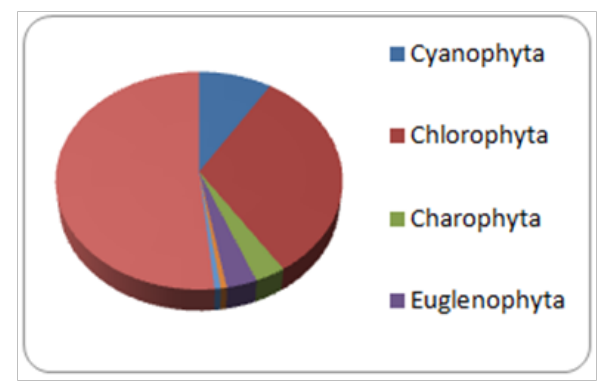

\section{Discussion}

There is no comparative resemblance to other natural or artificial bodies of water. The composition of microalgae genera in La Cantera artificial reservoir is evident, and it can be the result of several environmental factors inside and out this body of water. In addition, space-time variability of both abiotic and biotic factors and the intrinsic conditions of the genera and their life cycles also play a role. Oliva Martinez et al., ${ }^{9}$ generalizes to the level of country stating that phytoplankton is mainly composed of the taxa Bacillariophyceae (31.9\%), Cyanophyceae (18.24\%) and Chlorophyceae (17.4\%), within which there are genera or species indicative of water quality. Valeriano Riveros ${ }^{10}$ classifies the percentage of the number of genera in the lake at Valle de Bravo as follows: Cyanophyceae 26\%, Chlorophyceae $34.33 \%$, Bacillariophyceae 13.12\%, Euglenophyceae 3.3\%, Xantophyceae $1.1 \%$, other taxa complete $100 \%$. The phytoplanktonic composition in La Cantera is shown in Figure 3.

Several genera of the Bacillariophyceae were abundant during the seven-year sampling period: Ulnaria (4.59\%), considered to belong to scarcely polluted environments (oligosaprobiont to beta-mesosaprobiont); $;^{11}$ Achnanthes $(4.33 \%)$ is reported from less contaminated media but has been seen in places with scarce to heavy pollution; ${ }^{12}$ Aulacoseira $(4.19 \%)$, its two species have been found in Lake Cocibolca, Nicaragua, polluted with organic residues (Hernández González and Guerrero Avilés (repositorio.unan.edu. ni/2549/1/354.pdf): ${ }^{13}$ Rhoicosphenia (4.13\%), a genus considered to belong to scarcely disturbed and well oxygenated water; ${ }^{14}$ Surirella $(3.79 \%)$ important because they are usually found in lakes or bodies of water with high concentrations of salts or in shallow water; ${ }^{15} \mathrm{Nitzschia}$ $(3.90 \%)$ some of these species tolerate a wide range of environmental conditions ${ }^{16}$ and show hypertrophic conditions such as those registered at the Lerma River, ${ }^{14}$ Pinnularia (4.25\%) can be considered optional or facultative heterotrophic diatoms which enables them to reproduce in extreme ecosystems ${ }^{17}$ Sellaphora (3.79\%), its species $S$. pupula is an indicator of water highly contaminated with industrial discharges (Segura García et al., 2012) and even domestic discharges, and reported by several authors as belonging to eutrophic and hypertrophic environments. ${ }^{18}$ Also, Cyclotella and Cymbella, in smaller percentages (between 3.67 and 3.80\%). In La Cantera, Navicula had three species considered as indicators of poor water quality or pollution, along with Nitzchia and two species of Microscystis (Table 2).

Nitzschia palea is abundant in several sites highly contaminated by domestic wastewater. Many authors have written about it being typical of environments rich in organic matter. ${ }^{19-21}$ Navicula mutica is also abundant in places with high conductivity and high nutrient concentrations. ${ }^{9}$ The genus Achnanthes, especially A. minuttissima, is common in a wide range of environmental conditions. Gomphonema gracile was the dominant species, typical of this place. Different 
authors $^{22-24}$ recorded this species in eutrophic lakes; they tolerate pollution and eutrophication, caused by nitrogen compounds, better. ${ }^{25}$

Table 2 Indicator species of water quality in La Cantera

\begin{tabular}{ll}
\hline Cyanoprokaryota & Bacillariophyceae \\
\hline Microscystis novacekki & Achnanthes exigua \\
Microscystis protocystis & Achnanthidium minutissimum \\
& Gomphonema gracile \\
& Gomphonema parvulum \\
& Navicula cryptotenella \\
& Navicula radiosa \\
& Navicula trivialis \\
& Nitzschia communis \\
& Nitzschia palea \\
\hline
\end{tabular}

According to Duque and Donato, ${ }^{23}$ the species Coccinodiscus perforatus, Gomphonema gracile, G. parvalum, G. pseudoaugur and G. angustum, were only found in the eutrophic lake; these are found in water with high contents of organic matter from the discharge of effluents with faeces and blood from pig slaughter-houses. These species can quickly convert large quantities of phosphorus into polyphosphates. ${ }^{24,26}$ Stenoic species, indicators of eutrophication, were Coccinodiscus perforatus, Gomphonema gracile, G. parvalum, G. pseudoaugur, G. angustum.

In regards to cyanophytes, Peinador ${ }^{27}$ states that it is not possible to compare different sampling sites with the lists found in literature and that define the species and associations most frequently recorded in different areas because these lists are incomplete as, just as those found in this study, they belong to specific locations and are far from universal. This author also states that a species can be found in different contamination conditions that depend on other characteristics of the site or may even be different varieties of the same species. This could be quite possible given the taxonomic ignorance regarding this group of organisms in the tropics. In general terms, however, most of the genera of cyanobacteria recorded in this study have been reported by one or more authors as being typical of water contaminated with organic matter, for example Microcystis novasekki or M. protocystis.

Dere et al. ${ }^{16}$ wrote that some species from different Divisions, such as the genus Nitzchia, tolerate a wide range of hypertrophic conditions like those of the Lerma River Mexico, ${ }^{12}$ in this basin, small-sized species like $N$. palea and Eolimna, and medium to larger-sized ones like Ulnaria, and Nitzchia and Sellaphora, the latter from relatively less contaminated places, have been found. All of this underlines the coincidence of Nitzchia and Navicula being indicators in La Cantera of a polluted, nitrogen enriched environment.

Although several authors propose genera or species as pollution indicators, like Nitzchia or Navicula, some of them do not specify the type of contaminant which means there is not always a coincidence in the results as their presence or abundance depends on the integration of various environmental factors. In La Cantera there was a predominance of other genera of Bacillariophyceae (from the most abundant to the less abundant): Ulnaria, Achnanthes, Aulacoseira, Rhoicosphenia, Surirella, Pinnularia, Sellaphora and Nitzschia, the least frequent being Navicula. These genera were not associated to any particular nutrient, whether nitrogenous or phosphorous, as these nutrients far exceed the recorded concentrations (total nitrogen
$>500 \mu \mathrm{M}$ and total phosphorus maximums of $120 \mu \mathrm{M})$, besides high silicate content (between 20 to $40 \mathrm{mg} / \mathrm{L}$ ), which did not limit the abundance of Bacillariophyceae and which originates in igneous rock with high silicate content. There is a predominance of diatoms with sufficient silicate contents to justify their high percentage.

The most prominent genera of the Cyanoprokaryota taxa were: Anabaena, (11.41\%), Chroccocus (10.27\%) and Microscystis (8.75\%); these, according to Tomasini Ortiz and Pérez Morales et al., ${ }^{28}$ produce toxins that affect not only the zooplankton ${ }^{29}$ but also humans. Although they were found in high percentages, they still do not pose a danger to the zooplantonic community in La Cantera. It should be said that high concentrations of ammonium-ion were recorded in La Cantera; this ion inhibits the growth of cyanophytes, as recorded by Vintila and El-Shehawy (2007) with the species Nodularia spumigena, which is cosmopolite.

The chlorophytes that stood out in La Cantera were: Cladophora and Rhizoclonium, filamentous algae very abundant due to high concentrations of nitrogenated and phosphorated nutrients, as was seen on the rocky wall with percolations and runoffs, possibly fracture from the Ajusco hill. In this sampling site, during certain periods of time, a low dissolved oxygen content ( $30 \%$ saturation) was recorded, probably due to the input of organic matter used by this gas during its degradation..$^{30,31}$

\section{Conclussion}

The most frequent and abundant taxa was Bacillariophyceae with nine indicator species, the two most important ones of Navicula and Nitzschia, followed by the taxa Cyanoprokaryota with only two species, mainly of Microscystis which determined the poor water quality and which are indicators of eutrophication from nutrients (nitrogen and phosphorus) and physical factors (conductivity, temperature), from the runoffs of peripheral urban settlements and their activities, and from springs possibly from infiltrations and cracks in the Ajusco hill whose skirts have begun to be urbanized. The genera Anabaena and Chroccocus can also pollute the water.

\section{Acknowledgements}

The authors would like to thank Angel Ceballos and Salvador Hernández Pulido for their help with the tables and figures.

\section{Conflicts of interest}

The authors declare that there is no conflict of interest.

\section{Funding}

None.

\section{References}

1. Lot A. Illustrated guide of the East Quarry, environmental characterization and biological inventory. Executive Secretariat of the Ecological Reserve of Pedregal de San Ángel; Coordination of Scientific Research; National Autonomous University of Mexico. 2007. 253 p.

2. Ponce-Márquez ME, Ramírez Rodríguez R, Ramírez Vázquez M. Algae from the Oriente Quarry, San Angel Pedregal Ecological Reserve: Field and laboratory guide. Science Presses, UNAM. 2019. 152 p.

3. González-González J, Novelo-Maldonado E. Special techniques for collecting and preparing specimens of selected groups of plants: Algae. In: Lot A, Chiang F, Editors. Herbarium manual. National Flora Council of Mexico. 1986;47-54. 
4. Hoek van den C, Mann DG, Jahns HM. Algae. An introduction to phycology. Cambridge University Press. London. 1995. 623 p.

5. Komárek J, Kaštovský J, Mareš J, et al. Taxonomic classification of cyano prokaryotes (cyanobacterial genera) according to the polyphasic approach Preslia. 2014;86:295-335.

6. Round FE, Crawford RM, Mann DG. The Diatoms. Biology \& Morphology of the Genera. Cambridge University Press. 1996. 44 p.

7. Ettl H. Xantophyceae In: Süsswasserflora von Mitteleurope. Band, Stuttgarrt: Gustav Fischer. 1978;3(1):i-xiv.

8. Ettl H, Gardner G. Chlorophyta II. Tetrasporales, Chroocoales, Gloeodendrales. Gustav Fischer Verlag, Stuttgart. 1988.

9. Martínez de Fabricius AL, Maidana N, Gómez, et al. Distribution patterns of benthic diatoms in a Pampean river exposed to seasonal floods: the Cuarto River (Argentina). Biodiversity and Conservation. 2003;12(12):2443-2454.

10. Valeriano-Riveros ME, Vilaclara G, Castillo Sandoval FG, et al. Phytoplankton composition changes during water level fuctuations in a high-altitude, tropical reservoir. Inland Waters. 2014;4(3):337-348.

11. Céspedes Vargas E. Taxonomic analysis of the main diatom species (Bacillariophyceae) at six sites in the Sarapiquí River basin, Heredia, Costa Rica. Thesis. University of Costa Rica, Faculty of Sciences, School of Biology. 2014.

12. Hernández González S. Biological indicators of surface water quality of the Río Viejo sub-basin, using phytobents (Diatoms). Center for Research in Aquatic Resources of Nicaragua, CIRA / UNAN-Managua. 2012;20-23.

13. Hernández González, Guerrero Avilés. Diatomeas como indicadores biologicos de la calidad del agua en el lago cocibolca. UNAM. 1993;1-8.

14. Segura-García V, Enrique A, Cantoral-Uriza EA, et al. Epilithic diatoms (Bacillariophyceae) as indicators of water quality in the Upper Lerma River, Mexico. Hydrobiological. 2012;22(1):16-27.

15. Ramírez S, Hermes U, Zárate del V, et al. Biogenic silica solution in lake sediments used as bioindicators of water quality. $e-$ Gnosis [online] RedAl-C.org. 2007;5(4)

16. Dere SN, Dalkiron D, Karacaoglu A, et al. Relationship among epipelic diatom taxa, bacterial abundances and water quality in a highly polluted stream catchment, Bursa - Turkey. Environmental Monitoring and Assessment. 2006;112(1-3):1-22.

17. Morales Velasco S, Zalazar Sánchez A. The peripheral diatoms of lakes with different trophic status in the department of Cauca (Colombia). Blue Moon. 2012;1909-2474.

18. Mora D, Carmona J, Cantoral-Uriza E. Epilitic diatoms of the upper Laja river basin, Guanajuato, Mexico. Mexican Journal of Biodiversity. 2015;86(4):1024-1040.
19. Gómez N. Epipelic diatoms of a high contaminated basin from Argentina (MatanzaRiachuelo river): biotic indices and multivariate analysis. Aquatic Ecosystem Health \& Management. 1999;2(3):301-309.

20. Kelly MG, Whittton BA. The trophic Diatom Index: a new index for monitoring eutrophication in rivers. J appl Phycol. 1995;7(4):433-444.

21. Van Dam H, Mertens A, Sinkeldam J. A coded checklist and ecological indicator values of freshwater diatoms from the Netherlands. Netherlands Journal of Aquatic Ecology. 1994;28(1):117-133.

22. Lobo EA, Ben Da Costa A, Kirst A. Avaliacao da qualidade gives wate two streams Sampaio, Bonito e Grande, Municipality of Mato Leitao. RS. Brazil. Second to resolucao do CONAMA 20/86. Networks Magazine. Santa Cruz do Sul. 1999;4(2):129-146.

23. Duque SR, Donato JCH. Biology and ecology of freshwater phytoplankton in Colombia. No. 35 Divulgative Notebooks, Javeriana University, Faculty of Science. 1992. p. 21.

24. RamírezJJ. Contribution to the ecological and taxonomic knowledge of phytoplankton of some important water bodies for the Colombian electricity sector. University of Antioquia., Fondo FEN, ISA, Medellín. 1992. 77 p.

25. Donato Ch, Duque S, Monsejo L. Structure and dynamics of the Phytoplankton of the Laguna de Fúquene (Cundinamarca, Colombia). Colombian Academy of Exact, Physical and Natural Sciences Magazine. 2005;16(62):113-144.

26. Oliva G, Martínez M, Ramírez-Martínez G, et al. Diatomological characterization in three bodies of water of the wetlands of JilotepecIxtahuaca, State of Mexico. Hydrobiological. 2005;15(1):1-26.

27. Peinador M. Cyanobacteria as indicators of organic pollution. Tropical Biology Magazine. On-line versión. 1999.47(3):381-391.

28. Pérez Morales A, Quijano Scheggia SI, Olivos A, et al. Current status of the study of flowering-forming freshwater cyanobacteria in central Mexico. In: García-Mendoza E, Quijano-Scheggia SI, Olivos-Ortiz A, Núñez-Vázquez EJ, Editors. Harmful Algal Flowering in Mexico. Ensenada, Mexico. CICESE. 2016. 438 p.

29. Araiza Vásquez DA. Demographic responses of Moina macrocopa (Straus, 1820) in the presence of cyanotoxins of the rowing and boating track Virgilio Uribe, Xochimilco. Bachelor thesis. Faculty of Higher Studies, Iztacala. 2017. 49 p

30. CNA (Comisión Nacional del Agua). Water and Society, a history of hydraulic works in Mexico. Secretariat of Agriculture and Hydraulic Resources, Undersecretariat of Hydraulic Infrastructure. 1988. 299 p.

31. Oliva-Martínez MG, Godínez-Ortega JL, Zuñiga-Ramos CA. Biodiversity of phytoplankton of inland waters in Mexico. Mexican Journal of Biodiversity. 2014;85(1):54-61. 